\title{
Integrating Pedagogical Model for Simulation-Based Learning in Hospitality TVET Students: Attitudes and Satisfaction
}

Quah Wei Boon, Roseline Anak Kok, Azreena Aziz

To Link this Article: http://dx.doi.org/10.6007/IJARBSS/v11-i6/10195

DOI:10.6007/IJARBSS/v11-i6/10195

Received: 15 April 2021, Revised: 18 May 2021, Accepted: 30 May 2021

Published Online: 16 June 2021

In-Text Citation: (Quah et al., 2021)

To Cite this Article: Quah. W. B., Roseline, A. K., \& Aziz, A. (2021). Integrating Pedagogical Model for Simulation-Based Learning in Hospitality TVET Students: Attitudes and Satisfaction. International Journal of Academic Research in Business and Social Sciences, 11(6), 600-612.

Copyright: (c) 2021 The Author(s)

Published by Human Resource Management Academic Research Society (www.hrmars.com)

This article is published under the Creative Commons Attribution (CC BY 4.0) license. Anyone may reproduce, distribute, translate and create derivative works of this article (for both commercial and non-commercial purposes), subject to full attribution to the original publication and authors. The full terms of this license may be seen at: http://creativecommons.org/licences/by/4.0/legalcode

Vol. 11, No. 6, 2021, Pg. 600- 612

Full Terms \& Conditions of access and use can be found at http://hrmars.com/index.php/pages/detail/publication-ethics 


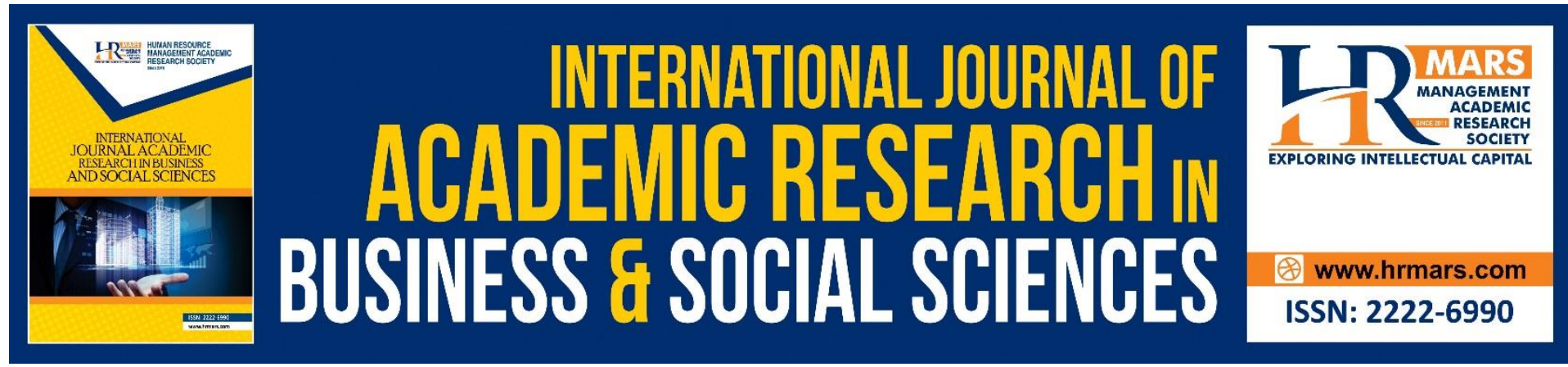

\title{
Integrating Pedagogical Model for Simulation- Based Learning in Hospitality TVET Students: Attitudes and Satisfaction
}

\author{
Quah Wei Boon¹, Roseline Anak Kok², Azreena Aziz ${ }^{3}$ \\ ${ }^{1}$ Unit Hotel Operation, Sungai Petani Community College, 08000 Kedah, Malaysia, \\ ${ }^{2}$ Department of Tourism \& Hospitality, Polytechnic of Tuanku Syed Sirajuddin, \\ 02600 Perlis, Malaysia, ${ }^{3}$ Unit Hotel Operation, Chenderoh Community College, \\ 33000 Perak, Malaysia \\ Email: skyman823000@yahoo.com, linshar20@gmail.com, azreena705@gmail.com
}

\begin{abstract}
Various teaching pedagogies have been used in hospitality programs. In this study, a new innovative teaching method has been implemented for TVET students in Sungai Petani Community College. This study aims to examine the attitudes and satisfaction of hospitality TVET students towards the use of the Front Office Tasks Simulator (FOTS) as an innovative teaching tool. This study is a descriptive study using a quantitative approach and data were collected through questionnaires answered by respondents. Purposive sampling techniques was used to select all hospitality education students in their 3rd semester year of college. In total, 22 students of the Hospitality Operations Program semester 3 participated in this study. The results found that students' attitude toward using FOTS as a whole was at a high level (M $=4.83, \mathrm{SD}=.14)$ and students' satisfaction using FOTS as a whole was also at a high level (M $=4.66, \mathrm{SD}=.52$ ). Pearson Correlation Test found that there was a significant relationship between students' attitudes and satisfaction in using FOTS as an innovative teaching tool for Front Office subjects $(r=.835, p<.01)$. In conclusion, the use of innovative teaching tools Front Office Tasks Simulator (FOTS) can increase students' understanding and satisfaction of learning the procedures of Doorman, Bellmen, and Concierge, reservation, check-in, checkout, payment of guest bills. For further research, researchers could evaluate the effectiveness of the simulation tool for community college graduates who work in a hotel or related hospitality industry after this simulation experience.

Keywords: Simulation-Based Learning, Attitude, Satisfaction, Hospitality TVET Students, Front Office Tasks Simulator
\end{abstract}

\section{Introduction}

Nowadays, educators are advised to integrate technology and innovate in students' teaching skills to meet the educational needs for the student learning experience, as stated in the Malaysia Education Plan 2015-2025 (Higher Education) (Ministry of Education Malaysia, 2016). Various teaching pedagogies have been used in hospitality programs in previous studies such as business simulations (Pratt \& Hahn, 2016), hotel simulations (Ampountolas, 
Shaw, \& James, 2018), Second Life (SL) as 3D virtual worlds in hospitality teaching (Deale, 2013), and active learning (Chau \& Cheung, 2017) to achieve specific course objectives. In hospitality classes in community colleges, traditional role-play is often used as one of the teaching and learning techniques. However, through the observation of researchers, the use of traditional role play is not very effective when students perform practical training for Front Office. Some problems have been identified as follows:

i. Students do not practice Front Office practical training seriously and correctly. Thus, students already have all the students' information as guests. When students are asked to perform practical exercises, students have neglected some important procedures such as taking important information from students as guests. For example, guests' details like student name, identity card number, and guest information.

ii. When students perform traditional role-play, only two students are involved at that time, and the other students do not concentrate and even make noise, and this will affect the performance and focus of students who are doing practical training.

iii. Students who perform practical role-playing exercises are difficult to get an idea and cannot imagine the real work situation or situation in the hotel because of the situation or environment in the lecture that does not reflect the real work situation.

iv. Students performing traditional role-playing exercises cannot see the continuity of workflow from one work procedure to another procedure such as the scope of Bellmen's task should start from the Front Office counter after guests have completed the Bellmen flat entry procedure should come and offer luggage lifting services, escort guests to rooms and explain the facilities in hotels and rooms even students do only one scope of work or one traditional role play only.

v. The lack of teaching aids in hospitality classes will make it difficult for students to understand the teaching and learning of Front Office subject procedures.

\section{Problem Statement}

As mentioned above, Sungai Petani Community College also often faces problems related to teaching and learning (T\&L) for Front Office subjects. Among the problems encountered are as follows:

The use of traditional role-play is ineffective in teaching and learning in Front Office subjects (Dickson, DiPietro, Iskat, \& Wirth, n.d.) Circumstances or environments in lectures that do not reflect actual or unconducive work situations (Ahmad, Shaharim, \& Yahaya, 2016; Saad, Yusoff, \& Yassin, 2011). Lack of teaching aids in hospitality classes (Chijioke \& Naade, 2018; Widiyatmoko \& Nurmasitah, 2013).

Accordingly, an alternative method or approach needs to be created so that students can understand and implement the Front Office practical procedures. In this study, an innovative idea that is Front Office Tasks Simulator (FOTS) has been produced and used in the hospitality class of Sungai Petani Community College to facilitate students to understand the procedure of doing check-in and check-out process, reservation procedure, guest billing procedure, Bellmen procedure, procedure Doorman and Concierge procedures. Front Office Tasks Simulator (FOTS) as an innovative teaching tool has been developed for Front Office simulation classes. The main purpose is to provide a simulated work environment for students 
to adapt to learning the actual activities of the check-in/check-out process that requires students to combine motor skills (data entry, credit card/cash processing) with customer service and orientation (welcoming and interacting with guests). Therefore, a study needs to be conducted to study the perceptions of Front Office students on the use of Front Office Tasks Simulator (FOTS) as an innovative teaching tool for Front Office subjects in community colleges.

\section{Research Objectives}

This study aims to examine the attitudes and satisfaction of hospitality students towards the use of the Front Office Tasks Simulator (FOTS) as an innovative teaching tool. In particular, this study has two objectives, namely:

i. to identify the attitudes and satisfaction of students using FOTS as an innovative teaching tool for Front Office subjects; and

ii. to determine the relationship between attitudes and student satisfaction using FOTS as an innovative teaching tool for Front Office subjects.

\section{Literature Review \\ Unconducive of Learning Environment}

According to Che Ahmad et al. (2016), the suitability of the learning environment is one of the determinants in the success of the learning process in the room. The findings state that the physical aspects of the room should be appropriate and meet the needs of teachers, students, and learning activities. This statement is supported by the study of Saad et al. (2011), that learning facilities such as rooms for teaching and to implement adequate practical are seen to influence students' learning while they are pursuing their studies at the Polytechnic. Meanwhile, Minhat (2011) stated that a positive lecture room atmosphere will not only encourage fun learning but also provide space for students to more easily and quickly understand the lesson in a more effective way.

\section{Lack of Teaching Aids}

In a study conducted by llias et al (2016), researchers stated that the use of teaching aids is important to improve students' memory of the lessons delivered. Meanwhile, Sharudin (2008) stated that the lack of tools and materials to do practical work will result in disrupted teaching and learning process.

\section{Simulation-Based Learning}

Training simulations are designed to reproduce or simulate processes, events, and situations that occur in a trainee's work. Trainees can experience these events in a controlled manner within a designated area, where they can develop their skills or discover concepts that will enhance their performance (Ahmmad, 2013). The purpose of the simulation method is to improve students' abilities and certain concepts in problem-solving. A simulation is a situation created to resemble a real situation but in a simplified form, summarized or minimized, so that related problems or issues are easier to solve.

In the study of Pratt and Hahn (2015), they concluded that simulations provide a beneficial learning experience through teamwork development, offer fun learning methods, and combine their knowledge from other courses. Another study conducted by Douglas, Miller, Kwansa, and Cummings (2008) adds to this finding that simulation has proven to be a useful 
tool for skill development essential for hospitality business management. In this study, the results show that the use of student simulation is positive.

\section{Front Office Tasks Simulator (FOTS) v2}

FOTS is used to create a real work situation/environment to perform practical. In particular, FOTS has combined four innovation ideas, namely:

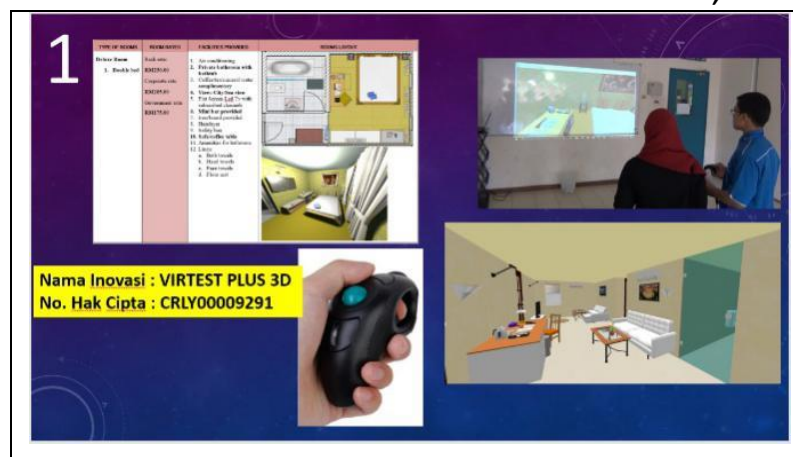

i. VIRTEST plus 3D $4^{\text {th }}$ version

Virtual guest room allows students to move the position of view and movement in the Virtual guest room. Students will see every item in the guest room, and this makes it easier for students to understand and explain items or facilities to guests.

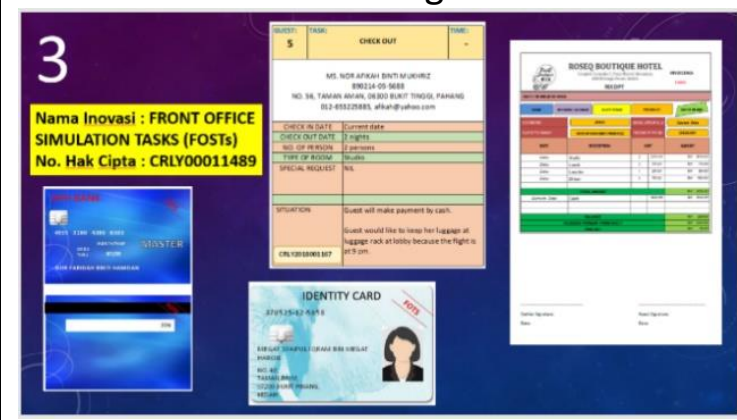

iii. Front Office Simulation Tasks $2^{\text {nd }}$ version

Is a Tasks Card to create a real workplace situation and environment that students will face for the scope of duties of Reservation Clerk, Receptionist, Cashier, Concierge, Doorman, and Bellman.

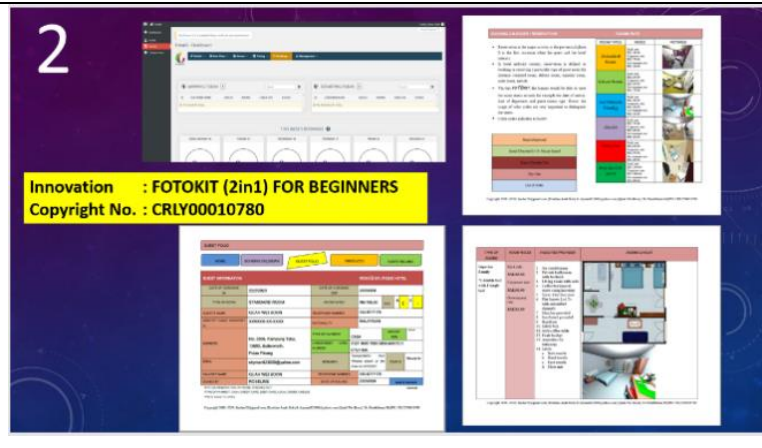

ii. FOTOKIT (2 in 1) for Beginners (manual \& online) $2^{\text {nd }}$ version

Has two versions, namely manual (laminate) and online allow students to practice the Front Office system simultaneously with reservation, checkin, check-out, and guest billing procedures.

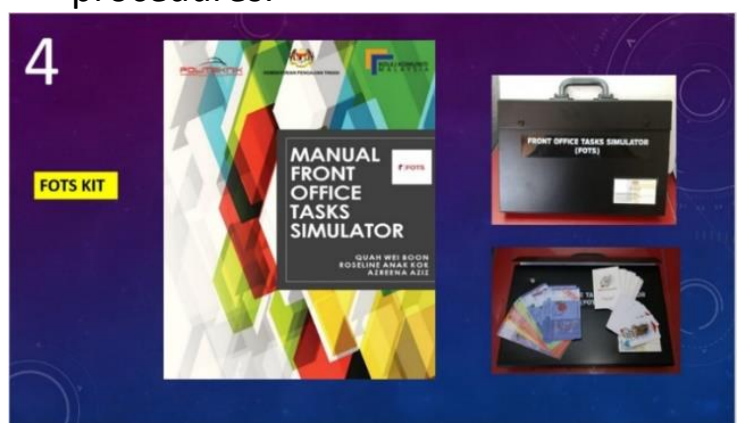

iv. Front Office Tasks Simulator Kit

This kit includes the manual for using this Simulator, specimen money, room key card, bills, receipts, and others to make it easier for lecturers and students to use. 


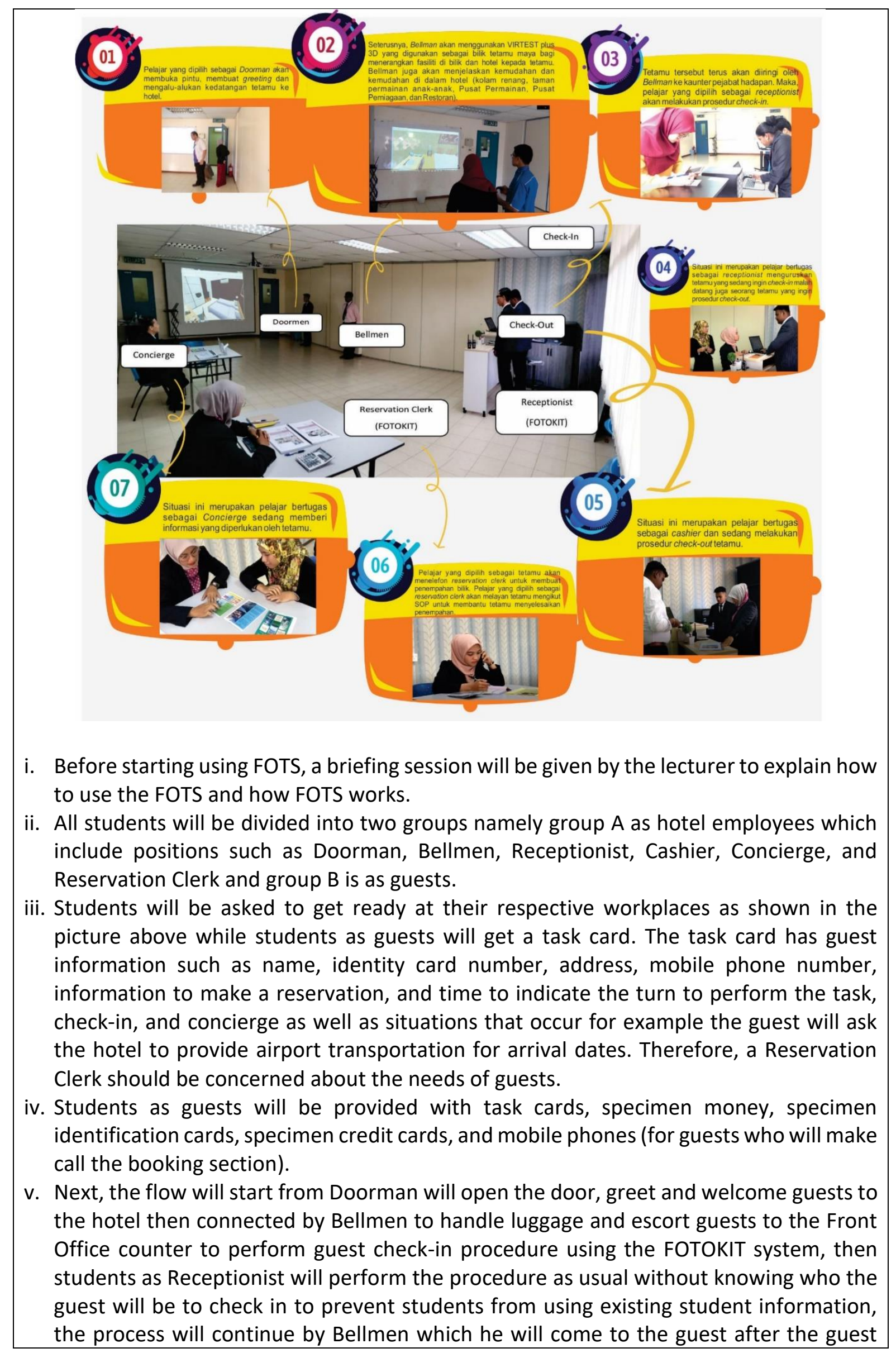


complete the check-in process, Bellmen will bring luggage and escort the guest to the guest room to explain hotel and room facilities by using VIRTEST plus 3D. When the Receptionist is entertaining guests, another guest will enter to perform the check-out process or to the concierge counter for the required information. With a flow of work procedure design that resembles a real-world situation in a hotel, students can see for themselves the workplace conditions that are full of hustle and bustle and surprise as they undergo industrial training at the hotel.

Fig. 1 The situation shows when FOTS is implemented

\section{Pedagogical Model for Simulation-Based Learning}

1. Pre-activities. Referring to the model of pedagogy in figure 2, the facilitator's task in the pre-activity phase is to design the teaching and learning process of the environment taking into account the learning objectives and characteristics of students. In this phase, the facilitator will design the appropriate scope of work in the task card to display the situation that will occur in the actual workplace. For example, in the task card, there is a scenario where guests need a special request such as the need to arrange a room to celebrate the Honeymoon to guests.

2. Introduction - activating prior knowledge \& setting the ground. In the first phase of simulation-based learning, the facilitator presents important course topics and concepts as well as explains the concept of simulation to students including its advantages and disadvantages. For example, the facilitator will present the use of FOTS, how the use of FOTS can help students better understand Front Office topics such as procedures as Doorman, Bellmen, Receptionist, Cashier, Concierge, and Reservation Clerk.

3. Simulator and scenario briefing - familisation. In this phase, the facilitator will introduce scenarios, guest situations, and a simulation-based learning environment including all the technologies that will be asked to use. Therefore, this phase should involve demonstrations and practical (hands-on) procedures as Doorman, Bellmen, Receptionist, Cashier, Concierge, and Reservation Clerk. When introducing a scenario, the facilitator will use real-world problems, situations, or examples as triggers for learning. For example, the facilitator will introduce the use of VIRTEST plus 3D for Bellmen use, the FOTOKIT system for Receptionist and Reservation Clerk to use, and Tasks card for creating the real workplace situation and environment.

4. Scenarios - guiding and participating. Phase 3 will form the main experience of simulationbased learning as students engage in this simulation. During this phase, students need to be active in treating guests as in real situations. In this phase, the facilitator needs to state clearly when the scenario begins and ends. For example, students as guests need to follow the instructions in the task card while doing the simulation.

5. Debriefing - Facilitating and Reflecting. While in this phase, students are responsible for studying and reviewing the learning process as well as identifying their knowledge gaps and forming new learning objectives. For example, when students treat guests there is a possibility that students do not remember some procedures, then students need to relearn their skills and knowledge. When giving a second briefing, a video recording will be used.

6. Post activities. This means that the facilitator should consider the facilitation process itself and the student's activities, as well as whether the learning objectives have been achieved to develop their teaching. Post activity is important for facilitators to develop simulationbased education. 


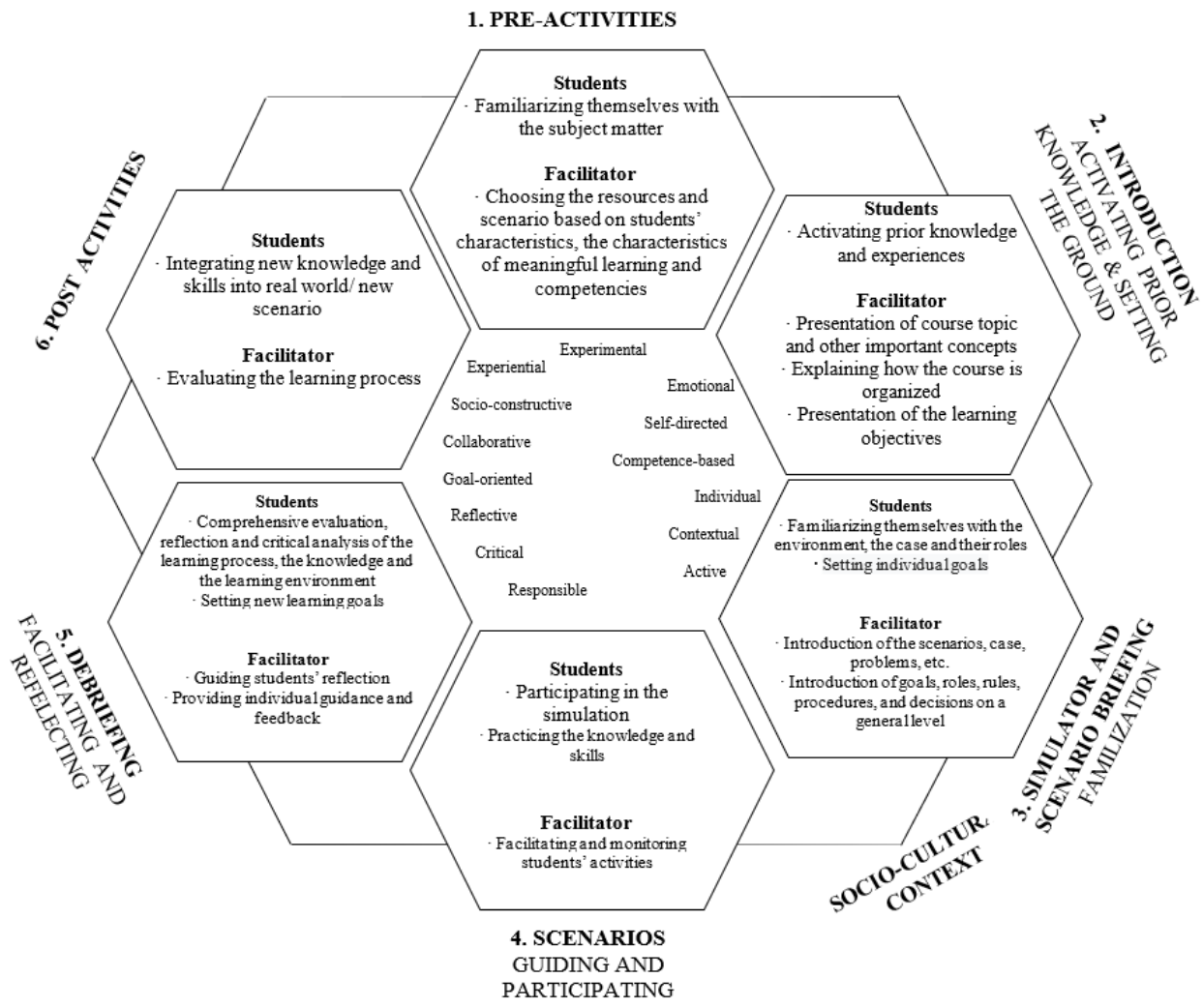

Fig. 2 The situation shows when FOTS is implemented Source: Keskitalo and Ruokamo (2015)

\section{Methodology}

This study is a descriptive study using a quantitative approach and data collected through questionnaires answered by respondents. Purposive sampling techniques was used to select all hospitality education students in their 3rd semester year of college. Thus, students in the 3 rd semester take the Front Office subject. Therefore, a total of 22 students were selected as a sample for this study. In this study, data were obtained through a questionnaire that was distributed to a total of 22 students. All 22 forms submitted have been received. The study was made using the Likert Scale, where there are five points of Likert Scale used, namely, strongly disagree, disagree, uncertain, agree, and strongly agree. The questionnaire is divided into 3 parts, namely part A - demographic, part B - attitude (instrument has been adapted and modified from the study of Davis (1989) and Pratt and Hahn (2016), and part C - satisfaction (instrument has been adapted and modified from Davis study) (1989) and Pratt and Hahn (2016). The data obtained were analyzed using descriptive analysis (personal details of students such as age, gender) and Pearson Correlation analysis (the relationship between student attitudes and student satisfaction with the use of FOTS.

\section{Findings}

\section{Profile of Respondents}

In terms of gender, the selected sample includes seven male students, which is $31.8 \%$, and 15 female students, which is $68.2 \%$. While for the age category, 21 respondents are $95.5 \%$ between $18-21$ years, and only one respondent is over 25 years. 


\section{Descriptive Analysis}

The mean value describes the propensity of each dependent variable and the independent variable. The classification analysis for the mean score and evaluation level was categorized into three levels, namely: 1.00-2.33 (low level), 2.34-3.67 (medium level), and 3.68-5.00 (high level/positive).

Table 1: Descriptive Analysis of Hospitality TVET Students' Attitudes Towards the Use of FOTS

\begin{tabular}{|c|c|c|c|c|}
\hline \multicolumn{2}{|c|}{ No. Items } & \multirow{2}{*}{$\begin{array}{l}\text { Mean } \\
4.59\end{array}$} & \multirow{2}{*}{$\begin{array}{l}\text { SD } \\
.796\end{array}$} & \multirow{2}{*}{\begin{tabular}{|l|} 
Level \\
Positive
\end{tabular}} \\
\hline 1 & Imitate the actual state of hospitality business. & & & \\
\hline 2 & $\begin{array}{l}\text { Front Office Tasks Simulator increased my focus on } \\
\text { learning compared to traditional learning. }\end{array}$ & 4.68 & .568 & Positive \\
\hline 3 & $\begin{array}{l}\text { Front Office Tasks Simulator can maintain my learning } \\
\text { performance. }\end{array}$ & 4.68 & .568 & Positive \\
\hline 4 & Front Office Tasks Simulator is easy to use. & 4.73 & .550 & Positive \\
\hline 5 & $\begin{array}{l}\text { Interacting with Front Office Tasks Simulator is clear and } \\
\text { easy to understand. }\end{array}$ & 4.68 & .568 & Positive \\
\hline 6 & $\begin{array}{l}\text { It is very easy for me to remember how to perform tasks } \\
\text { using Front Office Tasks Simulator }\end{array}$ & 4.64 & .581 & Positive \\
\hline 7 & $\begin{array}{l}\text { Front Office Tasks Simulator provides useful guides in } \\
\text { performing tasks. }\end{array}$ & 4.68 & .568 & Positive \\
\hline 8 & Likes to use Front Office Tasks Simulator & 4.59 & .796 & Positive \\
\hline 9 & Front Office Tasks Simulator is fun to use. & 4.64 & .658 & Positive \\
\hline 10 & Improve the quality of courses compared to others. & 4.55 & .671 & Positive \\
\hline & Overall mean score & 4.66 & .52 & Positive \\
\hline
\end{tabular}

Table 1 displays the data analysis for the variables of students' attitudes towards the Use of FOTS. Overall, the mean recorded for all items in the variables studied was 4.66 and the average standard deviation was .52. This study shows that students' attitude towards the use of FOTS in teaching and learning at Sungai Petani Community College is at a very satisfactory level. Item B4 shows a high level of mean interpretation of 4.73 (Front Office Tasks Simulator is easy to use). Meanwhile, Item B2 (Front Office Tasks Simulator increases my focus on learning compared to traditional learning) item B3 (Front Office Tasks Simulator can maintain my learning performance), and item B7 (Front Office Tasks Simulator provides a useful guide in carrying out tasks) is the second mean score the highest is 4.68. Next, Item B1 (Imitating the actual hospitality business situation) and item B8 (Like using Front Office Tasks Simulator) showed a mean score of 4.69. Item 10 (Improving the quality of the course compared to others) is the item with a low mean score of 4.55 . 
Table 2. Descriptive Analysis of Hospitality TVET Students' Satisfaction Towards the Use of FOTS

\begin{tabular}{|c|c|c|c|c|}
\hline No. & Items & Mean & SD & Level \\
\hline 1 & $\begin{array}{l}\text { Front Office Tasks Simulator is important for connecting } \\
\text { theory with practice. }\end{array}$ & 4.82 & .395 & High \\
\hline 2 & Front Office Tasks Simulator is an effective learning method. & 4.82 & .501 & High \\
\hline 3 & Front Office Tasks Simulator developed my teamwork skills & 4.68 & .477 & High \\
\hline 4 & $\begin{array}{l}\text { Learning through Front Office Tasks Simulator helped in } \\
\text { preparing me for the workforce. }\end{array}$ & 4.82 & .395 & High \\
\hline 5 & Front Office Tasks Simulator is a fun way of learning. & 4.73 & .631 & High \\
\hline 6 & $\begin{array}{l}\text { Using Front Office Tasks Simulator developed my decision- } \\
\text { making skills. }\end{array}$ & 4.73 & .550 & High \\
\hline 7 & $\begin{array}{l}\text { Front Office Tasks Simulator requires me to analyze the } \\
\text { current situation and find the best results. }\end{array}$ & 4.77 & .429 & High \\
\hline 8 & $\begin{array}{l}\text { Front Office Tasks Simulator is a practical method for } \\
\text { understanding hotel operations }\end{array}$ & 4.86 & .351 & High \\
\hline 9 & $\begin{array}{l}\text { Using Front Office Tasks Simulator gives me an } \\
\text { understanding of the interdependent relationships } \\
\text { between departments. }\end{array}$ & 4.86 & .351 & High \\
\hline 10 & $\begin{array}{l}\text { Front Office Tasks Simulator helps me learn about } \\
\text { management decisions. }\end{array}$ & 4.82 & .395 & High \\
\hline 11 & $\begin{array}{l}\text { Front Office Tasks Simulator provides an opportunity to } \\
\text { analyze my results. }\end{array}$ & 4.73 & .456 & High \\
\hline 12 & $\begin{array}{l}\begin{array}{l}\text { Scenario-based simulation is an effective learning } \\
\text { experience. }\end{array} \\
\end{array}$ & 4.86 & .351 & High \\
\hline 13 & $\begin{array}{l}\text { Simulations provide an opportunity to observe the cause and } \\
\text { effect of the decision relationship. }\end{array}$ & 4.77 & .429 & High \\
\hline 14 & $\begin{array}{l}\text { Using Front Office Tasks Simulator gives me the opportunity } \\
\text { to improve my problem solving skills }\end{array}$ & 4.77 & .528 & High \\
\hline 15 & $\begin{array}{l}\text { I learn more effectively through Front Office Tasks Simulator } \\
\text { than traditional assessment methods. }\end{array}$ & 4.64 & .658 & High \\
\hline 16 & $\begin{array}{l}\text { Front Office Tasks Simulator allows me to practice what I } \\
\text { learned in the previous topic. }\end{array}$ & 4.68 & .568 & High \\
\hline 17 & $\begin{array}{l}\text { Front Office Tasks Simulator provides a real learning } \\
\text { experience. }\end{array}$ & 4.86 & .351 & High \\
\hline 18 & $\begin{array}{l}\text { Front Office Tasks Simulator combines my knowledge from } \\
\text { other topics I studied }\end{array}$ & 4.73 & .550 & High \\
\hline 19 & Front Office Tasks Simulator mimics real life situations. & 4.64 & .848 & High \\
\hline 20 & $\begin{array}{l}\text { Front Office Tasks Simulator displays the problems I need to } \\
\text { solve. }\end{array}$ & 4.68 & .568 & High \\
\hline 21 & $\begin{array}{l}\text { Front Office Tasks Simulator complements conventional } \\
\text { classroom learning. }\end{array}$ & 4.73 & .550 & High \\
\hline \multicolumn{2}{|r|}{ Overall mean score } & 4.76 & .36 & High \\
\hline
\end{tabular}

Based on Table 2, items C8 (Front Office Tasks Simulator is a practical method for understanding hotel operations), C9 (Using Front Office Tasks Simulator gives me an 
understanding of the interdependence between departments), C12 (Scenario-based simulation is an effective learning experience) and C17 (Front Office Tasks Simulator provides real learning experience) got the highest mean score (mean score $=4.86$, standard deviation $=.351$ ). The second highest mean score is item C1 (Front Office Tasks Simulator is important to connect theory with practice), C2 (Front Office Tasks Simulator is an effective learning method), C4 (Learning through Front Office Tasks Simulator helps in preparing me for the workforce), and C10 (Front Office Tasks Simulator helped me learn about management decision making) (mean score $=4.82$ ). Items C7, C13, and C14 got the same mean score, and the third-highest (mean score $=4.77$ ). Items C5, C6, C11, C18, and C21 got the same mean score of 4.73, followed by items C3, C16, and C20 (mean score $=4.68$ ). While items C15 and C19 got the same and lowest mean score of 4.64. Despite getting the lowest mean score but this statement is still at a high level of mean interpretation. Overall, the mean value of the student satisfaction variable for the use of FOTS is 4.76. This finding shows that students' satisfaction with the use of FOTS in teaching and learning at Sungai Petani Community College is at a high level.

\section{Relationship between Attitude and Student Satisfaction with the use of FOTS}

The Pearson Correlation test was used to test the relationship between attitudes and student satisfaction with the use of FOTS. Table 3. shows that there is a significant relationship between attitudes and student satisfaction $(r=.835, p<.01)$. This indicates that student attitudes will affect student satisfaction with the use of FOTS.

Table 3: Pearson Correlation Between Attitudes And Student Satisfaction With Usage of FOTS

\begin{tabular}{|l|l|l|}
\hline Variables & & Satisfaction \\
\hline Attitude & Pearson Correlation & $.835^{* *}$ \\
\cline { 2 - 3 } & Sig. (2-tailed) & .000 \\
& $\mathrm{~N}$ & 22 \\
\hline \multirow{2}{*}{. Correlation is significant at the 0.01 (2-tailed) level }
\end{tabular}

\section{Discussion}

The results show that the overall mean for students' attitudes is at a high level. From the findings of the study, it was found that all the question items studied showed a high mean interpretation. This shows that students have a positive attitude towards the use of FOTS. Thus, FOTS can provide a real learning experience; FOST is easy to use; FOTS can increase my focus on learning compared to traditional learning and FOTS can maintain learning performance. Therefore, students' attitudes are positive because FOTS can have an impact on students.

The results of this study also show that the overall mean for student satisfaction is at a high level of 4.76. This is because FOST is a practical method for understanding hotel operations; the use of FOTS can give students an understanding of the interdependence between departments; scenario-based simulation in FOTS is an effective learning experience, and FOTS can provide a real learning experience. Therefore, when students get satisfaction in the use of FOTS then the level of student satisfaction will also increase.

The results of the next study were to test the relationship between attitudes and student satisfaction with the use of FOTS. The results show that there is a significant relationship 
between attitudes and student satisfaction. This finding indicates that student attitudes will affect student satisfaction with the use of FOTS. When students' attitudes are at a high level, then student satisfaction will also increase. This finding shows that the use of FOTS as an innovative teaching tool in teaching and learning among hospitality students, especially in the field of Front Office is appropriate.

\section{Conclusion}

Overall, this study shows that students' attitude and satisfaction with the use of FOTS in Hospitality Teaching and Learning in Sungai Petani Community College is high. As this study is very beneficial to institutions in upgrading the $T \& L$ process, further research is very important and useful to assist the Hospitality Operations Unit of Sungai Petani Community College, especially in further improving the quality of T\&L and students. It is hoped that the findings of this study will help the Hospitality Operations Unit in creating an attractive T\&L environment, interactive and interesting teaching aids and increase the level of use of the latest technology in the T\&L process to Sungai Petani Community College students so that not being left behind in this new era. For further research, researchers could evaluate the effectiveness of the simulation tool for community college graduates who work in a hotel or related hospitality industry after this simulation experience.

\section{References}

Ahmmad, S. (2013). Importance of training in hotel industry: A case study of Hilton Hotel, Cyprus (Master's thesis, Södertörns University). Retrieved from http://www.divaportal.org/smash/get/diva2:651957/fulltext01.pdf

Ampountolas, A., Shaw, G., \& James, S. (2018). Active learning to improve self-confidence and decision-making skills through the use of hotel simulation. Journal of Hospitality \& Tourism Education, 31(3), 125-138. doi: 10.1080/10963758.2018.1487786

Chau, S., \& Cheung, C. (2017). Bringing life to learning: A study of active learning in hospitality education. Asia-Pacific Education Researcher, 26(3-4), 127-136. doi: 10.1007/s40299-017-0333-6

Chijioke, O. P., \& Naade, N. B. (2018). Towards improving teachers' competences in the use of instructional materials in senior secondary schools' physics in Port Harcourt Metropolis, Rivers State. International Journal of Innovative Education Research, 6(1), 77-85. Retrieved from https://www.researchgate.net/publication/323857834

Davis, F. D. (1989). Perceived usefulness, perceived ease of use, and user acceptance of information technology. MIS Quarterly, 13, 319-340. doi: 10.2307/249008

Deale, C. S. (2013). Incorporating Second Life into online hospitality and tourism education: A case study. Journal of Hospitality, Leisure, Sport \& Tourism Education, 13, 154-160. doi: 10.1016/j.jhlste.2013.09.002.

Dickson, D. R., DiPietro, R., \& Iskat, W., \& Wirth, J. (n.d.). Playing in the classroom: The use of role play in hospitality education. Retrieved from https://www.hrbartender.com/images/playing.pdf

Douglas, A. C., Miller, B., Kwansa, F., \& Cummings, P. (2008). Students' perceptions of the usefulness of a virtual simulation in post-secondary hospitality education. Journal of Teaching in Travel \& Tourism, 7(3), 1-19. doi: 10.1080/15313220801909270

Ilias, M. F., Husain, K., Noh, M. A., Rashed, Z. N., \& Abdullah, M. (2016). Sumber bahan bantu mengajar dalam kalangan guru pendidikan islam sekolah bestari. e-Academia J., 
5(2), 106-114. Retrieved from

http://myjms.moe.gov.my/index.php/JeA/article/view/1301

Keskitalo, E. T., \& Ruokamo, H. (2015). A pedagogical model for simulation-based learning in healthcare. International Journal of Media, Technology and Lifelong Learning, 11(2), 7486. Retrieved from https://pdfs.semanticscholar.org/7864/d82747b0919ccc10ae7020aa66600f5e1dc6.pdf

Saad, M. A., Yusoff, N. M. R., \& Yassin, M. R. (2011). Penilaian kemudahan pembelajaran, peruntukan kewangan dan kursus dalam perkhidmatan bagi kursus Pendidikan Islam di Politeknik Malaysia. Journal of Islamic and Arabic Education, 3(1), 123-134. Retrieved from http://www.ukm.edu.my/jiae/pdf/30.pdf

Minhat, N. (2011). Kepuasan pelajar terhadap kemudahan yang disediakan di Politeknik Tuanku Syed Sirajuddin. Retrieved from https://www.academia.edu/7951978

Ministry of Education Malaysia. (2016). Malaysia blueprint 2015-2025 (Higher Education). Retrieved from http://mohe.gov.my/muat-turun/awam/penerbitan/pppm-2015-2025pt/5-malaysia-education-blueprint-2015-2025-higher-education

Pratt, M. A., \& Hahn, S. (2015). Effects of simulation on student satisfaction with a capstone course. Journal of Hospitality \& Tourism Education, 27(1), 39-46. doi: 10.1080/10963758.2015.998911

Pratt, M. A., \& Hahn, S. (2016). Enhancing hospitality student learning through the use of a business simulation. Journal of Hospitality, Leisure, Sport \& Tourism Education, 19, 1018. doi: 10.1016/j.jhlste.2016.05.001

Sharudin, S. T. (2008). Faktor yang mempengaruhi keberkesanan pengajaran dan pembelajaran di dalam bengkel vokasional di dua buah sekolah menengah teknik di Negeri Sembilan (Master's thesis, Universiti Teknologi Malaysia). Retrieved from http://eprints.utm.my/5898/1/PSM_JILID-TQAH.pdf

Widiyatmoko, A., \& Nurmasitah, S. (2013). Designing simple technology as a science teaching aids from used materials. Journal of Environmentally Friendly Processes, 1(4), 26-33. doi: 10.14266/jefp14-1 